\title{
Effectiveness of Ginseng in Treating Erectile Dysfunction: A Review Paper
}

\author{
Amy Ting Shy Yee*, Lee Tiong Chan \\ Jeffrey Cheah School of Medicine and Health Sciences, Monash University Malaysia, Subang Jaya, Malaysia \\ Email: *atin0001@student.monash.edu
}

How to cite this paper: Yee, A.T.S. and Chan, L.T. (2021) Effectiveness of Ginseng in Treating Erectile Dysfunction: A Review Paper. Open Access Library Journal, 8: e8043. https://doi.org/10.4236/oalib.1108043

Received: October 2, 2021

Accepted: October 26, 2021

Published: October 29, 2021

Copyright (C) 2021 by author(s) and Open Access Library Inc.

This work is licensed under the Creative Commons Attribution International License (CC BY 4.0).

http://creativecommons.org/licenses/by/4.0/

\begin{abstract}
Early identification and treatment of erectile dysfunction (ED) and ED related comorbidities, including hypertension, diabetes mellitus, and hyperlipidemia is crucial in improving the quality of life of men and their partners. To date, the main treatment options for ED can be divided into pharmacological and surgical interventions. These treatments include oral phosphodiesterase type 5 (PDE5) inhibitors (sildenafil, tadalafil, vardenafil), intraurethral or intracavernosal alprostadil, vacuum devices and penile prosthesis. Although considerable advances have been made, there seems to be a high dropout rate of the above treatment due to cultural restrictions and taboos. Subsequently, these patients would seek herbal dietary supplements such as ginseng as an alternative. Even though several studies have proved that ginseng is ideal in treating $\mathrm{ED}$, the published trials on humans were not robust, and there is a lack of exploration of subjective outcomes. This literature review aimed to synthesize and critically appraise clinical and scientific literature on the effects of ginseng in managing ED. In total, 7 studies were included and reviewed. It was concluded that ginseng is a feasible alternative to currently available practices in treating ED due to a significant improvement in International Index of Erectile Function (IIEF)-5 scores and its safety profile. There is a higher likelihood to consider ginseng as an alternative therapy if more studies with larger-scaled clinical trials and higher standards on the safety and efficacy of ginseng are conducted in the future.
\end{abstract}

\section{Subject Areas}

Andrology

\section{Keywords}

Erectile Dysfunction, Ginseng, Effectiveness, Treatment 


\section{Introduction}

Interest surrounding erectile dysfunction and its treatments has been persistent throughout centuries as penis erection has always represented man's sexual prowess. Erectile dysfunction (ED) is the recurrent or persistent incapacity to maintain or achieve an adequate penile erection to obtain satisfactory sexual performance [1]. Worldwide, around 150 million men are unable to either obtain or sustain an erection. Age is proven to have the strongest association with ED. Research showed that the occurrence of moderate ED doubles from $17 \%$ to $34 \%$ and that severe ED triples from $5 \%$ to $15 \%$ in men aged 40 to 70 [2]. ED is often caused by psychogenic and organic factors, where $80 \%$ of cases have an organic aetiology [1]. Atherosclerotic disease such as diabetes mellitus, hypertension and heart disease is reckoned to account for $40 \%$ of cases [3] [4] [5]. Sexual dysfunctions are also common in haemodialysis patients and male kidney transplant recipients [6]. From a clinical point of view, ED also acts as an indicator of systemic endothelial dysfunction, where ED may be used as an early marker for cardiovascular events [1] [5]. Therefore, it is important for a primary care physician to identify ED early as other modifiable risk factors and comorbidities could be treated simultaneously when a patient presents with ED [7]. The quality of life of men and their partners could be improved with the early intervention [8].

Reflexogenic and psychogenic are the two distinct central erection mechanisms of the penile erection. Reflexogenic erection is achieved by exteroceptive stimulation of the penile shaft and is regulated by a sacral spinal nerve mechanism. Psychogenic erection utilizes the limbic system of the brain and is initiated by sensory and imaginative stimuli [1] [9] [10].

Relaxation of intracavernosal smooth muscle is an essential process in penile erection. The corpora cavernosa becomes engorged with blood, compressing on the emissary veins, thus decreasing venous outflow from the penis [11]. When there is sexual stimulation, excitatory signals originate in the brain, and the signals travel through the parasympathetic nervous system to parasympathetic nerves of the S2-S4 sacral plexus. The signals travel to cavernosal nerves in the penis from the sacral plexus, which release nitrous oxide (NO) from its terminal end. This nitrous oxide initiates an erectile process, whereas nitrous oxide from endothelial cells are responsible to maintain it. When nitrous oxide enters the intracavernosal smooth muscle, the muscle relaxes, causing an arterial flow to increase with concurrent veno-occlusive activity. All these result in a rigid erection. When corporal smooth muscle contracts again, the process reverses. ED arises if pathology from any of the above processes arises [12].

Currently, the main treatment options for ED can be divided into pharmacological and surgical interventions [13] [14]. Examples of pharmacotherapy include oral phosphodiesterase type 5(PDE5) inhibitors (sildenafil, tadalafil, vardenafil), and the surgical interventions, namely intraurethral or intracavernosal alprostadil, vacuum devices, and penile prosthesis [15] [16] [17] [18]. PDE5-inhi- 
bitors act as a first-line therapy as they have favourable safety profiles and are highly effective [19]. Most of the patients respond well to the drug reactions [20]. These drugs prevent cyclic GMP from being neutralised by PDE5 enzyme, thus lengthening the penile erection [20] [21]. Studies demonstrated no significant difference in safety and efficacy among the different types of PDE5-inhibitors [15].

However, treatment failure due to patient and clinician issues and drug allergic reactions forces patients to opt for second-line therapies such as alprostadil and vacuum devices [15] [20]. Alprostadil relaxes the cavernosal smooth muscle through cyclic AMP synthesis, leading to penile erection [22] [23] [24]. Alprostadil remains an excellent treatment option, but fear of needles and severe adverse event, which is penile fibrosis, can limit patient acceptance [15] [17]. Vacuum constriction devices, which are relatively safe, are usually offered to the elders with satisfaction rates ranging between $27 \%$ and $94 \%$ [15] [16] [17]. The reasons for a low acceptance rate among younger patients include the unnatural erection and delay in erection [15] [17]. Penile prosthesis remains as a last resort in treating ED. It is only recommended when all the medical treatments have failed and when patients have developed a severe allergic reaction to the medication. Due to its invasiveness, high cost, risk of recurrent infections and other complications such as changes in sensation during erection and ejaculation, reduction in and penile length and urethral injury, the penile implant remains as a third-line therapy for ED [15] [17] [25] [26].

Although considerable advances have been made, there seems to be a group of patients who are reluctant to comply with western treatments due to cultural restrictions and taboos, resulting in a high dropout rate of the above treatment [27] [28]. Subsequently, these patients would seek alternatives such as herbal dietary supplements [18]. Among the wide range of herbal products, ginseng, which has a rich medicinal history of over 2000 years, has garnered popularity in treating ED and other ED related comorbidities, including hypertension, diabetes mellitus, and hyperlipidemia [29]. Ginsenosides (GS), the major primary active agents in ginseng, have been shown to enhance nitric oxide (NO) production, thus improving vascular endothelial abnormalities. Research studies postulated that with enhanced nitric oxide synthesis in the endothelium of lung, heart, kidney and corpus cavernosum, ginseng possesses antioxidant and organ-protective action in the human body [30]. Several studies also showed that ginsenosides cause a dose-dependent relaxation of corpus cavernosal smooth muscle in rabbits through the release of nitrous oxide [11] [31] [32] [33] [34]. Choi et al. (1995) also concluded that ginseng significantly improved patient satisfaction and penile girth [35].

Nevertheless, insufficient evidence is available to evaluate the exact efficacy of ginseng as the published trials on humans were not robust, and there is a lack of exploration of subjective outcomes. Therefore, we conducted this review aiming to synthesize and critically appraise clinical and scientific literature on the effects of ginseng in managing ED. 


\section{Efficacy of Ginseng in ED-Related Comorbidities}

We analyzed the efficacy of Ginseng in ED-related comorbidities including hypertension, diabetes mellitus and hyperlipidemia.

\subsection{Hypertension}

Hypertension can be a risk factor for ED; similarly, ED can be one of the early signs of hypertension. During hypertension, vasculature structural changes such as increase in collagen deposition and decrease in lumen diameter can be seen. These vascular changes may affect penile vasculature, resulting in diminished blood supply to the penis. Impairment in the balance between vasodilators and vasoconstrictors due to sustained release of procontracatile agents could also be found during hypertension. These agents widely affect the erectile structures as there will be a widespread release of reactive oxygen species, which is detrimental to endothelium and smooth muscle [36] [37].

Research demonstrated that consumption of ginseng causes transient vasodilation and in some cases, it is followed by vasoconstriction, culminating in a rise in blood pressure. While ginseng can elevate blood pressure, this generally occurs with low blood pressure, which helps to restore blood pressure to normal. Blood circulation has been shown to be improved with the vasodilation action of Panax ginseng. Korean red ginseng, which has lower doses of GS, has an antihypertensive effect. GS activates eNOS activation, therefore, causing a surge in NO production. Research proposed that GS activates the calcium-activated potassium channels in vascular smooth cells, which decreases calcium influx, thus vasodilation occurs [38]. Furthermore, when aqueous extracts of Panax notoginseng and salvia miltiorrhiza were mixed together, the mixture demonstrated antihypertensive effects by inhibiting arterial myogenic responses. In a nutshell, ginseng improves blood circulation and normalizes blood pressure [39].

\subsection{Diabetes Mellitus}

$\mathrm{ED}$ is common in diabetic men with a prevalence of $\geq 50 \%$ [40]. In diabetes-induced erectile dysfunction (DIED), elevated advanced glycation end-products (AGEs) lead to atherosclerosis and vascular thickening. Moreover, sustained release of oxygen free radicals give rise to oxidative cell damage and smooth muscle relaxation impairment. Levels of NO synthesis are significantly impaired in DIED, culminating in cavernosal and smooth muscle dysfunction. Diabetes is known to manifest microvascular complications, mostly peripheral and autonomic neuropathy [41]. This situation is documented by longer latency in abnormal bulbar urethral and urethroanalreflexes [42].

The hypoglycemic effect of ginseng's active ingredient has been known since the 1980s. GS was revealed to activate adenosine monophosphate-activated protein kinase (AMPK), which suppresses hepatic gluconeogenesis. AMPK causes a surge in glucose uptake into skeletal or adipose tissue and stimulates glucose 
metabolism by improving mitochondrial biogenesis, where people with type 2 diabetes have mitochondrial function deficit. Excess amounts of triglyceride in muscles, which is associated with insulin resistance, could be reduced through activation of AMPK. Besides, ginseng increases insulin production and ensures cell viability in pancreatic islet cells [43]. Recent animal studies revealed that ginseng enhances glucose transporter-2 proteins in the livers of mice and glucose uptake into sheep red blood cells [44]. In short, ginseng holds promise as a therapeutic agent for diabetes treatment.

\subsection{Hyperlipidemia}

The lipid profile in ED patients predominantly shows high levels of total cholesterol/high-density lipoprotein (TC/HDL) and low levels of high-density lipoprotein (HDL). Higher levels of HDL appeared to be beneficial as it carries cholesterol away from tissues to the liver, where it can be excreted. Hyperlipidemia causes arterial stenosis and occlusion, which further exacerbates ED. The peripheral nerves, endothelial cells, and smooth muscles for penile erection are further damaged by hyperlipidemia [45]. Hyperlipidemia is also linked to decrease in NO production, followed by impairment of endothelium relaxation, leading to failure of penile relaxation during erection [46].

Studies have shown that ginseng improves lipid profile by lowering serum total cholesterol, LDL, and triglyceride levels while elevating serum HDL levels [47]. AMPK, which is activated through a rise in intracellular AMP: ATP ratio, plays a role in ameliorating hyperlipidemia. AMPK activation increases ketogenesis and fatty acid oxidation with concurrent inhibition of fatty acids, hepatic lipogenesis and cholesterol synthesis. The action of ginseng in improving lipid profile can be seen in an animal study. The study, conducted by Yuan et al. (2010), showed that saponins increase cholesterol excretion through acid bile formation, thus decreasing blood cholesterol levels in prolonged cholesterol-fed rabbits [48]. Another animal study showed that saponins as GS promote the synthesis of LDL receptors in rats, thus increasing LDL receptors. Furthermore, present results reported that long-term administration of ginseng in obese patients improved HDL level while cholesterol level was decreased [49]. After all, ginseng has beneficial effects as an anti-hyperlipidemic agent.

\section{Efficacy of Ginseng in Treating ED}

We review seven studies [2] systematic reviews and 5 randomized controlled trials (RCTs)] to examine the efficacy of ginseng in treating ED. Most of these trials were conducted in Asian populations, mainly Korean. In these trials, the efficacy of ginseng on ED was determined using the International Index of Erectile Function (IIEF) [27] [50]-[55], Rigiscan [27] [51], questionnaires related to erectile function [51] [54], global assessment questionnaire (GAQ) [53] and premature ejaculation diagnostic tool (PEDT) [52]. The main findings and conclusion is presented in Table 1. 
Table 1. List of included articles in this review with main study findings and conclusion.

\begin{tabular}{|c|c|c|c|c|c|}
\hline $\begin{array}{l}\text { Study, year, } \\
\text { country }\end{array}$ & Design & $\begin{array}{l}\text { Participant } \\
\text { characteristics }\end{array}$ & Intervention & Main outcomes & Author's conclusion \\
\hline \multicolumn{6}{|c|}{ systematic review/Meta-analysis } \\
\hline $\begin{array}{l}\text { Jang et al. } \\
{[54], 2008} \\
\text { Korea }\end{array}$ & $\begin{array}{l}\text { Systematic } \\
\text { review }\end{array}$ & $\begin{array}{l}7 \text { relevant trials } \\
\text { which evaluated } \\
363 \text { men aged } \\
\text { from } 24 \text { - } 70 \\
\text { years old who } \\
\text { had ED for } 1 \text { to } \\
30 \text { years }\end{array}$ & $\begin{array}{l}\text { In } 4 \text { trials: } 600 \mathrm{mg} \\
\text { red ginseng } 3 \text { times } \\
\text { daily } \\
\text { In } 2 \text { trials: } 900 \mathrm{mg} \\
\text { red ginseng } \\
\text { In } 1 \text { trial: } 1000 \mathrm{mg} \\
\text { red ginseng }\end{array}$ & $\begin{array}{l}\text { - International Index of } \\
\text { Erectile Function (IIEF) } \\
\text { - Watts sexual function } \\
\text { questionnaire } \\
\text { - global efficacy question } \\
\text { (mainly for erection } \\
\text { sufficient for normal } \\
\text { satisfaction) } \\
\text { - author made structural } \\
\text { interview questionnaires } \\
\text { related to erectile } \\
\text { function }\end{array}$ & $\begin{array}{l}6 \text { RCTs showed therapeutic } \\
\text { efficacy of red ginseng } \\
\text { compared with placebo } \\
\text { control. }\end{array}$ \\
\hline
\end{tabular}

\begin{tabular}{|c|c|c|c|c|c|}
\hline $\begin{array}{l}\text { Borrelli et al. } \\
\text { [50], } 2018 \\
\text { Italy }\end{array}$ & $\begin{array}{l}\text { Systematic } \\
\text { review and } \\
\text { meta-analysis }\end{array}$ & $\begin{array}{l}2080 \text { patients } \\
\text { with ED }\end{array}$ & $\begin{array}{l}12 \text { mono } \\
\text { preparations: } 5 \\
\text { ginseng, } 3 \text { saffron, } 1 \\
\text { Pinus pinaster } 1 \\
\text { Lepidium meyenii, } \\
2 \text { Tribulus } \\
\text { terrestris, } 7 \\
\text { evaluated } \\
\text { formulations, } 5 \\
\text { dietary supplements } \\
\text { with pure } \\
\text { compounds }\end{array}$ & $\begin{array}{l}\text { International Index of } \\
\text { Erectile Function [IIEF]-5 } \\
\text { or IIEF-15 }\end{array}$ & $\begin{array}{l}\text { Ginseng significantly } \\
\text { improved ED. P. pinaster and } \\
\text { L. meyenii showed positive } \\
\text { results, and saffron and T. } \\
\text { terrestri treatment produced } \\
\text { mixed results. Several herba } \\
\text { formulations were associated } \\
\text { with a decrease of IIEF- } 5 \text { or } \\
\text { IIEF-15. }\end{array}$ \\
\hline
\end{tabular}

Randomised controlled trials (RCTs)

\begin{tabular}{|c|c|c|c|c|c|}
\hline $\begin{array}{l}\text { Andrade et } \\
\text { al. [53], } 2007 \\
\text { Brazil }\end{array}$ & $\begin{array}{l}\text { Double-blind, } \\
\text { placebo- } \\
\text { controlled study } \\
(\mathrm{RCT})\end{array}$ & $\begin{array}{l}60 \text { patients with } \\
\text { mild or mild to } \\
\text { moderate ED }\end{array}$ & $\begin{array}{l}1000 \mathrm{mg} \text { of Korean } \\
\text { Red Ginseng(KRG) } \\
\text { or a placebo } 3 \text { times } \\
\text { daily }\end{array}$ & $\begin{array}{l}\text { - International Index of } \\
\text { Erectile Function } \\
\text { [IIEF]-5 } \\
\text { - global assessment } \\
\text { questionnaire (GAQ) }\end{array}$ & $\begin{array}{l}\text { The IIEF- } 5 \text { score after the } \\
\text { treatment was significantly } \\
\text { higher in the KRG group } \\
\text { compared with that before the } \\
\text { treatment. There was no } \\
\text { difference before and after the } \\
\text { treatment in the placebo } \\
\text { group. As for the GAQ, there } \\
\text { were significant improvements } \\
\text { in erection in the treatment } \\
\text { group as compared to placebo. }\end{array}$ \\
\hline $\begin{array}{l}\text { Choi et al. } \\
{[51], 1995} \\
\text { Korea }\end{array}$ & RCT & $\begin{array}{l}33 \text { patients } \\
\text { with borderline } \\
\text { organic and } \\
\text { psychogenic ED }\end{array}$ & $\begin{array}{l}\text { Korean red ginseng } \\
\text { (daily) or a placebo } \\
\text { for } 3 \text { months }\end{array}$ & $\begin{array}{l}\text { - Questionnaire to survey } \\
\text { self-reported status of } \\
\text { libido, erection, } \\
\text { ejaculation, sexual } \\
\text { performance, satisfaction } \\
\text { rate of intercourse } \\
\text { - Rigiscan }\end{array}$ & $\begin{array}{l}\text { All parameters surveyed have } \\
\text { shown improvements } \\
\text { compared to the controls. } 4 \\
\text { out of } 6 \text { patients showed } \\
\text { rigidity of more than } 70 \% \text { after } \\
\text { consumption of ginseng. }\end{array}$ \\
\hline $\begin{array}{l}\text { Choi et al. } \\
{[52], 2012} \\
\text { Korea }\end{array}$ & $\begin{array}{l}\text { multicenter, } \\
\text { placebo - } \\
\text { controlled, } \\
\text { double-blind } \\
\text { clinical study } \\
\text { (RCT) }\end{array}$ & $\begin{array}{l}119 \text { men with } \\
\text { mild-to-modera } \\
\text { te ED }\end{array}$ & $\begin{array}{l}4 \text { tablets of either } \\
\text { standardized } \\
\text { Korean ginseng } \\
\text { berry (berry SKGB, } \\
350 \text { mg ginseng } \\
\text { berry extract per } \\
\text { tablet), or placebo, } \\
\text { daily, for } 8 \text { weeks }\end{array}$ & $\begin{array}{l}\text { - International Index of } \\
\text { Erectile Function } \\
\text { (IIEF)-15 } \\
\text { - premature ejaculation } \\
\text { diagnostic tool (PEDT) }\end{array}$ & $\begin{array}{l}\text { IIEF-15 score increased } \\
\text { significantly in the SKGB by } \\
\text { the } 8 \text { th week. PEDT scores } \\
\text { significantly improved in the } \\
\text { SKGB group after } 4 \text { and } 8 \\
\text { weeks of treatment. }\end{array}$ \\
\hline
\end{tabular}




\begin{tabular}{|c|c|c|c|c|c|}
\hline $\begin{array}{l}\text { Kim et al. } \\
{[55], 2009} \\
\text { Korea }\end{array}$ & $\begin{array}{l}\text { double-blind, } \\
\text { placebo- } \\
\text { controlled study } \\
\text { (RCT) }\end{array}$ & $\begin{array}{l}143 \text { patients } \\
\text { with ED }\end{array}$ & $\begin{array}{l}1000 \mathrm{mg} \text { of } \\
\text { tissue-cultured } \\
\text { mountain ginseng } \\
\text { extract (TGME) or } \\
1000 \mathrm{mg} \text { of placebo } \\
\text { twice a day for } 8 \\
\text { weeks }\end{array}$ & $\begin{array}{l}\text { Korean version of } \\
\text { International Index of } \\
\text { Erectile Function (IIEF) } \\
\text { questionnaire }\end{array}$ & $\begin{array}{l}\text { The scores of } 5 \text { domains of } \\
\text { IIEF after medication were } \\
\text { significantly higher than } \\
\text { baseline scores in the group } \\
\text { treated with TGME. No } \\
\text { significant improvement was } \\
\text { observed in the placebo group. }\end{array}$ \\
\hline $\begin{array}{l}\text { Hong et al. } \\
\text { [27], } 2002 \\
\text { Korea }\end{array}$ & $\begin{array}{l}\text { double-blind, } \\
\text { placebo } \\
\text { controlled, } \\
\text { crossover study } \\
\text { (RCT) }\end{array}$ & $\begin{array}{l}45 \text { patients with } \\
\text { ED }\end{array}$ & $\begin{array}{l}900 \mathrm{~g} \text { of Korean red } \\
\text { ginseng or placebo } \\
3 \text { times daily ( } 8 \\
\text { weeks on treatment, } \\
2 \text { weeks of washout } \\
\text { and } 8 \text { weeks on } \\
\text { treatment) }\end{array}$ & $\begin{array}{l}\text { - International Index of } \\
\text { Erectile Function (IIEF) } \\
\text { - Rigiscan } \\
\text { - Penile duplex } \\
\text { ultrasonography }\end{array}$ & $\begin{array}{l}\text { Mean IIEF scores were } \\
\text { significantly higher in patients } \\
\text { treated with Korean red } \\
\text { ginseng than in those who } \\
\text { received placebo. Among other } \\
\text { variables, penile tip rigidity on } \\
\text { Rigiscan showed significant } \\
\text { improvement for ginseng } \\
\text { versus placebo. }\end{array}$ \\
\hline
\end{tabular}

Jang et al. (2008) conducted a systematic review in 2008 evaluating the effectiveness of red ginseng for treating ED. The systematic review was conducted on 7 RCTs, including 363 men from 24 - 70 years old with ED that lasted for 1 to 30 years. Among the seven trials, four trials, two trials, and one trial adopted 600 $\mathrm{mg}$ ginseng three times daily, $900 \mathrm{mg}$ once daily, and $1000 \mathrm{mg}$ once daily, respectively. Six of the included trials compared the therapeutic efficacy of red ginseng with placebo. The meta-analysis indicated that red ginseng is superior to placebo [ $\mathrm{n}=349$, risk ratio (RR), 2.40 ; $95 \% \mathrm{CI}$ of $1.65,3.51, \mathrm{p}<0.00001]$. Moreover, subgroup analyses also revealed beneficial outcomes of red ginseng in patients with psychogenic ED ( $\mathrm{n}=135, \mathrm{RR}, 2.05 ; 95 \% \mathrm{CI}$ of $1.33,3.16, \mathrm{p}=0.001)$. All these RCTs showed that red ginseng is effective in treating erectile dysfunction. However, a more rigorous study is necessary due to the small sample size [54].

In the study by Borrelli et al. (2018), 2080 patients with ED were recruited, and 12 types of mono preparations were introduced to them. These mono preparations included 5 ginsengs ( $\mathrm{n}=399), 3$ saffron $(\mathrm{n}=397), 2$ Tribulus terrestris ( $\mathrm{n}$ $=202), 1$ Pinus pinaster $(\mathrm{n}=21)$ and 1 Lepidium meyenii $(\mathrm{n}=50)$. Besides, 5 investigated dietary supplements with pure compounds $(n=410)$ and 7 evaluated formulations $(\mathrm{n}=544)$ were involved. The IIEF-5 score was significantly improved by ginseng (140 for ginseng, 96 for placebo) with standardized mean difference of 0.43 (95\% confidence interval [CI] $0.15-0.70, \mathrm{P}<0.01)$. Saffron and $T$. terrestris showed mixed results, whereas $P$. pinaster and $L$. meyenii produced positive preliminary results. With these encouraging results, ginseng may be an effective herbal treatment for ED. However, more rigorous research in the field is required before a firm conclusion can be drawn. A degree of familiarity with the safety and efficacy of ginseng used in ED should be established to ensure the patients are being properly counselled and treated [50].

De Andrade et al. (2007) accessed the efficacy of Korean Red Ginseng (KRG) using IIEF-5 and GAQ. In the KRG group, the IIEF-5 score after the treatment was significantly improved compared with that before the treatment $(16.4 \pm 2.9$ 
to $21.0 \pm 6.3, \mathrm{P}<0.0001)$. On the other hand, in the placebo group, there was no difference before and after the treatment $(17.0 \pm 3.1$ to $17.7 \pm 5.6, \mathrm{P}>0.05)$. Besides, the total score for questions 3 and 5 in IIEF- 5 improved significantly after treatment, with $\mathrm{P}<0.001$ and $\mathrm{P}<0.0001$, respectively. In the global efficacy question, 20 patients $(66.6 \%)$ in the KRG group appeared to have improved erection which was significant $(\mathrm{P}<0.01)$, while there was no difference in the placebo group. With these results, KRG plays a beneficial role in treating ED [53].

In a previous study done by Choi et al. (1998), a questionnaire that surveyed the self-reported status of libido, erection, ejaculation, sexual performance and satisfaction rate of intercourse was used to determine the efficacy of KRG in patients with borderline psychogenic and organic erectile dysfunction. Besides, Rigiscan was also used to determine the outcome. On an objective questionnaire, the clinical efficacy of KRG was $66.7 \%$ and $72.2 \%$ on subjective analysis. All parameters included in the questionnaire were enhanced compared to the placebo. After evaluating erectile function using Rigiscan, 4 out of 6 patients treated with KRG showed penile rigidity greater than $70 \%$. In conclusion, KRG has been proven effective in Koreans as it has beneficiary action on male erectile functions with minimal adverse events [51].

A multicenter placebo-controlled, double-blind clinical study which was conducted in 2012 established the efficacy of standardized Korean ginseng berry (SKGB) using IIEF-5 and PEDT. By 8th week of treatment, the total scores and each domain score of IIEF-5 in the SKGB group have significantly improved from $40.95 \pm 7.05$ to $46.19 \pm 12.69(\mathrm{P}<0.05)$. The domain score for erectile function improved slightly from $17.17 \pm 2.57$ to $18.59 \pm 5.99$ for those who had consumed SKGB. On the other hand, PEDT, which evaluates ejaculatory function, increased slightly from the baseline score of $9.14 \pm 4.57$ to $7.97 \pm 4.4$ and $7.53 \pm 4.26$, respectively, after 4 and 8 weeks of treatment $(\mathrm{P}<0.05)$. Therefore, ginseng can be used as an alternative treatment for ED [52].

In 2009, Kim et al. conducted a double-blind, placebo-controlled study in Korea on 143 patients experiencing ED. IIEF was applied to gauge the efficacy of tissue-cultured mountain ginseng extract (TMGE). After two months of treatment, the total IIEF score of the TMGE group had significantly improved from $29.78 \pm 13.14$ to $39.86 \pm 15.29(\mathrm{P}<0.001)$. The improvement observed in the placebo group was not statistically significant as it only increased slightly from $29.71 \pm 10.58$ to $33.33 \pm 10.17$ ( $\mathrm{P}>0.05)$. In the TMGE group, the domain score for intercourse satisfaction and overall satisfaction improved to $6.83 \pm 2.95$ and $5.74 \pm 1.93$ respectively after eight weeks of medication $(\mathrm{P}=0.001$ for both). On the other hand, the placebo group showed no statistical significance of increment for both domains. Based on these results, the authors concluded that TMGE could be utilized for improving erectile function in male patients [55].

Hong et al. (2002) conducted a double-blind crossover study which included 45 patients with ED. Korean version of IIEF, Rigiscan, and penile duplex ultra- 
sonography were used to determine the efficacy of KRG. After treatment, the mean IIEF scores were significantly improved in patients receiving ginseng than in those who received placebo where in the KRG group the total IIEF scores increased to $38.1 \pm 16.6$ versus $30.9 \pm 15.7$ in the placebo group $(\mathrm{p}<0.01)$. Domain scores for erectile function, sexual desire and intercourse satisfaction also significantly improved after treatment. Nevertheless, the mean scores for orgasmic function and overall satisfaction domains showed no significant difference after treatment. On Rigiscan, there was a significant improvement in penile tip rigidity after treatment with ginseng with a baseline of $34.27 \% \pm 33.11 \%$ and $44.5 \% \pm$ $28.84 \%$ versus $40.42 \% \pm 30.21 \%$ ( $\mathrm{p}<0.05$ ). On penile duplex ultrasonography, the mean end-diastolic velocity changed from $4.15 \pm 3.94$ to $3.82 \pm 3.79$ versus $4.08 \pm 3.38$ with ginseng and placebo, respectively $(\mathrm{p}=0.708)$. On the other hand, the mean peak systolic velocity on duplex ultrasonography increased from $35.39 \pm 19.13$ to $39.48 \pm 22.29$ and $37.45 \pm 20.01$ in treatment and placebo groups, respectively $(\mathrm{p}=0.534)$. All in all, this study proved that Korean red ginseng could be used as an alternative for treating ED [27].

\section{Discussion}

Ginseng has been used as an adaptogen to boost health and a popular aphrodisiac to enhance ED and sexual performance for thousands of years [56]. In this review, all these trials reached a similar conclusion: ginseng is ideal in treating ED where IIEF- 5 scores were significantly improved after treating with ginseng [27] [50] [52] [53] [54] [55]. Similar to multiple study findings, Borrelli et al. also revealed a positive outcome of ginseng on four of the five IIEF-15 domains: improving sex desire $(P<0.01)$, erectile function $(P=0.01)$, erection maintenance $(\mathrm{P}<0.01)$ and overall satisfaction $(\mathrm{P}=0.01)$. However, domain scores such as orgasmic function showed no significant improvement after treatment $(\mathrm{P}=0.06)$ [28]. Khera and Goldstein (2011), which reviewed Panax ginseng data from six RCTs, concluded that approximately $58 \%$ of men who consumed ginseng experienced sexual function improvement as compared with $20 \%$ of patients who received placebo [2]. Ernst et al. (2011) also arrived at a similar conclusion as Khera and Goldstein (2011) where the experts concluded that Panax ginseng was the only herbal supplement test that received a cautiously positive conclusion without apparent safety issues [2] [57]. Another subgroup analysis again showed ginseng had a significant positive effect on the psychogenic aetiology of sexual dysfunction $(P=0.001)$ and reported no significant side effects [12]. Similarly, a study conducted among Japanese adult patients with low domain scores for erectile function and low libido concluded that the intercourse satisfaction, libido and penile circumference were significantly improved with ingestion of Sanchi ginseng extract capsules [58]. No major safety concerns were reported with the consumption of ginseng in this study.

In this review, we also observed that ginseng can also treat ED-related comorbidities such as hypertension, diabetes mellitus and hyperlipidemia. Evidence 
has shown that the action of GS in ginseng enhances vascular endothelial abnormalities and possesses organ-protective action, especially in lungs, heart, and corpus cavernosum [59]. In a human study that included 26 patients with essential hypertension, ginseng has been shown to significantly lower the systolic blood pressure $(\mathrm{p}=0.03)$, whereas the diastolic pressure remained unchanged ( $\mathrm{p}$ $=0.17$ ) [38] [60]. Wood et al. (1964), who conducted an animal study, found approximately $25 \mathrm{mmHg}$ of transient reduction in blood pressure after a bolus injection of ginseng extract into the dogs [61]. A reduction in blood pressure can reduce the risk of myocardial infarction by at least $16 \%$ and stroke by $35 \%-40 \%$ [62] [63]. Sotaniemi et al. (1995) proposed that $200 \mathrm{mg}$ of ginseng reduced fasting blood glucose and improved HbAlc [64]. Another study conducted by Vuksan et al. (2018) also resulted in similar conclusion as Sotaniemi et al. where ginseng decreased HbAlc and fasting blood glucose levels with $\mathrm{p}$ value of 0.041 and 0.008 respectively [65].

Another animal study showed positive outcomes of ginseng in treating diabetes mellitus where it was found that the antioxidant effect of ginseng prevents ED from occurring in non-insulin-dependent diabetes mellitus rats as oxidative stress is one of the chief factors in causing ED in diabetics [66]. In an animal study, Bakircioglu et al. (2000) demonstrated that rats treated with Chinese herbal medicine have increased levels of caveolin-1 expression, protecting the penile smooth muscles from detrimental effects of high cholesterol level thus resulting in better erectile response [67]. Kim et al. (2003) concluded that the triglyceride, total cholesterol level and low-density lipoprotein levels were reduced after two months of ginseng administration [49]. Besides that, weight and fat mass have been reduced significantly after the consumption of ginseng [68].

In terms of the safety of ginseng, the US National Institutes of Health to the US National Toxicology Program nominated Panax ginseng to assess its carcinogenic potential. Tumorigenicity, safety, and chronic toxicity of ginseng were examined in multiple studies in mice and rats. In the 2-week, 3-month, or 2-year gavage studies, no significant safety issues were reported. Therefore, researchers concluded that even when ginseng was administered at a dose of $5000 \mathrm{mg} / \mathrm{kg}$, it was neither tumorigenic nor toxic [69]. No safety issues of concern have been noted in the past laboratory studies exploring the effect of Panax ginseng on sexual function. For instance, the researchers reported that even with doses up to $20 \mathrm{~g} / \mathrm{kg}$, there was no animal mortality in the most recent investigation. Besides, in another ancillary study by this same group, the beagle dogs showed no signs of toxicity when treated with a primary ginsenoside (Rg1) at a dose of $500 \mathrm{mg} / \mathrm{kg}$ by mouth daily for five months [69].

Moreover, the consistency of safety data from human studies is derived from different sources and is notable. For instance, a 2002 analysis included all articles with original data on adverse events and drug interactions with Panax ginseng. Information was also requested from twelve manufacturers regarding preparations of ginseng, national drug safety bodies, and the World Health Organiza- 
tion. The incidence of side effects of ginseng was found to be similar to that of placebo. An update to this manuscript, which was done in 2009, came to a similar conclusion and stated that the potential for drug-ginseng interactions is "low" [69].

\section{Conclusion}

Based on this review, it is shown that ginseng improved IIEF-5 scores, normalized blood pressure, blood glucose level, and lipid profile. Ginseng as a monopreparation showed a safe profile with no significant differences between the ginseng and placebo groups in terms of the symptoms and frequency of side effects in RCT studies with a small number of subjects with various conditions for each patient. Therefore, ginseng could be a popular and useful alternative therapy considering that many patients are reluctant to use potentially invasive pharmaceutical drugs to achieve an erection. However, due to the small sample sizes, and methodological quality of preliminary trials, the possible utility of ginseng in everyday clinical practice would be reduced. On that account, more studies with larger-scaled clinical trials and higher standards on the safety and efficacy of ginseng are needed to develop more definite factual information about ginseng as complementary medicine to the consumers. More trials which involved Caucasian populations and comparison of ginseng with other established ED interventions are also worth to be considered.

\section{Acknowledgements}

We would like to express our gratitude to the Monash University Library as we can utilize the extensive resources, especially full-text articles and software (EndNote) to complete this review paper.

\section{Conflicts of Interest}

The authors declare no conflicts of interest.

\section{References}

[1] Yafi, F.A., Jenkins, L., Albersen, M., Corona, G., Isidori, A.M., Goldfarb, S., et al. (2016) Erectile Dysfunction. Nature Reviews Disease Primers, 2, Article No. 16003. https://doi.org/10.1038/nrdp.2016.3

[2] Khera, M. and Goldstein, I. (2011) Erectile Dysfunction. BMJ Clinical Evidence, 2011, Article No. 1803.

[3] Davis, M.P. and Behm, B. (2019) Ginseng: A Qualitative Review of Benefits for Palliative Clinicians. American Journal of Hospice and Palliative Medicine ${ }^{\circledast}, 36,630-659$. https://doi.org/10.1177/1049909118822704

[4] Hackett, G. (2009) The Burden and Extent of Comorbid Conditions in Patients with Erectile Dysfunction. International Journal of Clinical Practice, 63, 1205-1213. https://doi.org/10.1111/j.1742-1241.2009.02088.x

[5] Wyllie, M.G. (2005) The Underlying Pathophysiology and Causes of Erectile Dysfunction. Clinical Cornerstone, 7, 19-26. https://doi.org/10.1016/S1098-3597(05)80045-6 
[6] Sy, S., Samaké, M., Yattara, H., Coulibaly, M., Koné, I., Fofana, A.S., et al. (2020) Erectile Dysfunction in Chronic Hemodialysis Patients at the University Hospital Center of Point-G in Mali. Open Journal of Clinical Diagnostics, 10, 29-40. https://doi.org/10.4236/ojcd.2020.101003

[7] Grover, S.A., Lowensteyn, I., Kaouache, M., Marchand, S., Coupal, L., DeCarolis, E., et al. (2006) The Prevalence of Erectile Dysfunction in the Primary Care Setting: Importance of Risk Factors for Diabetes and Vascular Disease. Archives of Internal Medicine, 166, 213-219. https://doi.org/10.1001/archinte.166.2.213

[8] Glina, S., Cohen, D.J. and Vieira, M. (2014) Diagnosis of Erectile Dysfunction. Current Opinion in Psychiatry, 27, 394-399. https://doi.org/10.1097/YCO.0000000000000097

[9] de Groat, W. (2017) Autonomic Nervous System: Central Urogenital Control. In: Reference Module in Neuroscience and Biobehavioral Psychology, Elsevier, Amsterdam. https://doi.org/10.1016/B978-0-12-809324-5.01816-2

[10] Shamloul, R. and Ghanem, H. (2013) Erectile Dysfunction. The Lancet, 381, 153-165. https://doi.org/10.1016/S0140-6736(12)60520-0

[11] MacKay, D. (2004) Nutrients and Botanicals for Erectile Dysfunction: Examining the Evidence. Alternative Medicine Review, 9, 4-16.

[12] Sooriyamoorthy, T. and Leslie, S.W. (2021) Erectile Dysfunction (Impotence). StatPearls, Treasure Island.

[13] Andersson, K.-E. (2011) Mechanisms of Penile Erection and Basis for Pharmacological Treatment of Erectile Dysfunction. Pharmacological Reviews, 63, 811-859. https://doi.org/10.1124/pr.111.004515

[14] Levine, L.A. (2000) Diagnosis and Treatment of Erectile Dysfunction. The American Journal of Medicine, 109, 3-12. https://doi.org/10.1016/S0002-9343(00)00655-0

[15] Hatzimouratidis, K. and Hatzichristou, D.G. (2005) A Comparative Review of the Options for Treatment of Erectile Dysfunction. Drugs, 65, 1621-1650. https://doi.org/10.2165/00003495-200565120-00003

[16] Mobley, D.F., Khera, M. and Baum, N. (2017) Recent Advances in the Treatment of Erectile Dysfunction. Postgraduate Medical Journal, 93, 679-685.

https://doi.org/10.1136/postgradmedj-2016-134073

[17] Rew, K.T. and Heidelbaugh, J.J. (2016) Erectile Dysfunction. American Family Physician, 94, 820-827.

[18] Wespes, E., Amar, E., Hatzichristou, D., Montorsi, F., Pryor, J. and Vardi, Y. (2002) Guidelines on Erectile Dysfunction. European Urology, 41, 1-5. https://doi.org/10.1016/S0302-2838(01)00008-2

[19] Palit, V. and Eardley, I. (2010) An Update on New Oral PDE5 Inhibitors for the Treatment of Erectile Dysfunction. Nature Reviews Urology, 7, 603-609. https://doi.org/10.1038/nrurol.2010.165

[20] Masuku, N.P., Unuofin, J.O. and Lebelo, S.L. (2020) Promising Role of Medicinal Plants in the Regulation and Management of Male Erectile Dysfunction. Biomedicine \& Pharmacotherapy, 130, Article ID: 110555. https://doi.org/10.1016/j.biopha.2020.110555

[21] Hatzimouratidis, K., Salonia, A., Adaikan, G., Buvat, J., Carrier, S., El-Meliegy, A., et al. (2016) Pharmacotherapy for Erectile Dysfunction: Recommendations from the Fourth International Consultation for Sexual Medicine (ICSM 2015). The Journal of Sexual Medicine, 13, 465-488. https://doi.org/10.1016/j.jsxm.2016.01.016

[22] Heidelbaugh, J.J. (2010) Management of Erectile Dysfunction. American Family Phy- 
sician, 81, 305-312.

[23] Muneer, A., Kalsi, J., Nazareth, I. and Arya, M. (2014) Erectile Dysfunction. BMJ, 348, Article No. g129. https://doi.org/10.1136/bmj.g129

[24] Nguyen, H.M.T., Gabrielson, A.T. and Hellstrom, W.J. (2017) Erectile Dysfunction in Young Men-A Review of the Prevalence and Risk Factors. Sexual Medicine Reviews, 5, 508-520. https://doi.org/10.1016/j.sxmr.2017.05.004

[25] Akin-Olugbade, O., Parker, M., Guhring, P. and Mulhall, J. (2006) Determinants of Patient Satisfaction Following Penile Prosthesis Surgery. The Journal of Sexual Medicine, 3, 743-748. https://doi.org/10.1111/j.1743-6109.2006.00278.x

[26] Minervini, A., Ralph, D.J. and Pryor, J.P. (2006) Outcome of Penile Prosthesis Implantation for Treating Erectile Dysfunction: Experience with 504 Procedures. BJU International, 97, 129-133. https://doi.org/10.1111/j.1464-410X.2005.05907.X

[27] Hong, B., Ji, Y.H., Hong, J.H., Nam, K.Y. and Ahn, T.Y. (2002) A Double-Blind Crossover Study Evaluating the Efficacy of Korean Red Ginseng in Patients with Erectile Dysfunction: A Preliminary Report. The Journal of Urology, 168, 20702073. https://doi.org/10.1016/S0022-5347(05)64298-X

[28] Park, N.C., Kim, S.W., Hwang, S.Y. and Park, H.J. (2019) Efficacy and Safety of an Herbal Formula (KBMSI-2) in the Treatment of Erectile Dysfunction: A Preliminary Clinical Study. Investigative and Clinical Urology, 60, 275-284. https://doi.org/10.4111/icu.2019.60.4.275

[29] Lee, A.-R., Gautam, M., Kim, J., Shin, W.-J., Choi, M.-S., Bong, Y.-S., et al. (2011) A Multianalytical Approach for Determining the Geographical Origin of Ginseng Using Strontium Isotopes, Multielements, and 1H NMR Analysis. Journal of Agricultural and Food Chemistry, 59, 8560-8567. https://doi.org/10.1021/jf201696j

[30] Kiefer, D.S. and Pantuso, T. (2003) Panax ginseng. American Family Physician, 68, 1539-1542.

[31] Choi, Y., Xin, Z. and Choi, H. (1998) Effect of Korean Red Ginseng on the Rabbit Corpus Cavernosal Smooth Muscle. International Journal of Impotence Research, 10, 37-43. https://doi.org/10.1038/sj.ijir.3900300

[32] Choi, Y.D., Rha, K.H. and Choi, H.K. (1999) In Vitro and in Vivo Experimental Effect of Korean Red Ginseng on Erection. The Journal of Urology, 162, 1508-1511. https://doi.org/10.1016/S0022-5347(05)68349-8

[33] Kim, H., Woo, D., Lee, G. and Kim, J. (1998) The Relaxation Effects of Ginseng Saponin in Rabbit Corporal Smooth Muscle: Is It a Nitric Oxide Donor? British Journal of Urology, 82, 744-748. https://doi.org/10.1046/j.1464-410X.1998.00811.x

[34] O'Hara, M., Kiefer, D., Farrell, K. and Kemper, K. (1998) A Review of 12 Commonly Used Medicinal Herbs. Archives of Family Medicine, 7, 523-536. https://doi.org/10.1001/archfami.7.6.523

[35] Choi, H., Seong, D. and Rha, K. (1995) Clinical Efficacy of Korean Red Ginseng for Erectile Dysfunction. International Journal of Impotence Research, 7, 181-186.

[36] de Oliveira, A.A. and Nunes, K.P. (2021) Hypertension and Erectile Dysfunction: Breaking Down the Challenges. American Journal of Hypertension, 34, 134-142. https://doi.org/10.1093/ajh/hpaa143

[37] Nunes, K.P., Labazi, H. and Webb, R.C. (2012) New Insights into HypertensionAssociated Erectile Dysfunction. Current Opinion in Nephrology and Hypertension, 21, 163-170. https://doi.org/10.1097/MNH.0b013e32835021bd

[38] Karmazyn, M. and Gan, X.T. (2021) Chemical Components of Ginseng, Their Biotransformation Products and Their Potential as Treatment of Hypertension. Mo- 
lecular and Cellular Biochemistry, 476, 333-347. https://doi.org/10.1007/s11010-020-03910-8

[39] Kim, J.-H. (2012) Cardiovascular Diseases and Panax ginseng. A Review on Molecular Mechanisms and Medical Applications. Journal of Ginseng Research, 36, 16-26. https://doi.org/10.5142/jgr.2012.36.1.16

[40] Thorve, V.S., Kshirsagar, A.D., Vyawahare, N.S., Joshi, V.S., Ingale, K.G. and Mohite, R.J. (2011) Diabetes-Induced Erectile Dysfunction: Epidemiology, Pathophysiology and Management. Journal of Diabetes and Its Complications, 25, 129-136. https://doi.org/10.1016/j.jdiacomp.2010.03.003

[41] Agarwal, S., Prakash, A. and Singh, N. (2003) Erectile Dysfunction in Diabetes Mellitus: Novel Treatments. International Journal of Diabetes in Developing Countries, 23, 94-98.

[42] Vernet, D., Cai, L., Garban, H., Babbitt, M.L., Murray, F.T., Rajfer, J., et al. (1995) Reduction of Penile Nitric Oxide Synthase in Diabetic BB/WORdp (Type I) and BBZ/WORdp (Type II) Rats with Erectile Dysfunction. Endocrinology, 136, 57095717. https://doi.org/10.1210/endo.136.12.7588327

[43] Yuan, H.-D., Kim, J.T., Kim, S.H. and Chung, S.H. (2012) Ginseng and Diabetes: The Evidences from in Vitro, Animal and Human Studies. Journal of Ginseng Research, 36, 27-39. https://doi.org/10.5142/jgr.2012.36.1.27

[44] Vuksan, V., Sievenpiper, J.L., Koo, V.Y., Francis, T., Beljan-Zdravkovic, U., Xu, Z., et al. (2000) American Ginseng (Panax quinquefolius L) Reduces Postprandial Glycemia in Nondiabetic Subjects and Subjects with Type 2 Diabetes Mellitus. Archives of Internal Medicine, 160, 1009-1013. https://doi.org/10.1001/archinte.160.7.1009

[45] Kim, S.-C. (2000) Hyperlipidemia and Erectile Dysfunction. Asian Journal of Andrology, 2, 161-166.

[46] Roumeguere, T., Wespes, E., Carpentier, Y., Hoffmann, P. and Schulman, C. (2003) Erectile Dysfunction Is Associated with a High Prevalence of Hyperlipidemia and Coronary Heart Disease Risk. European Urology, 44, 355-359. https://doi.org/10.1016/S0302-2838(03)00306-3

[47] Yamamoto, M., Uemura, T., Nakamura, S., Uemiya, M. and Kumagai, A. (1983) Serum HDL-Cholesterol-Increasing and Fatty Liver-Improving Actions of Panax ginseng in High Cholesterol Diet-Fed Rats with Clinical Effect on Hyperlipidemia in Man. The American Journal of Chinese Medicine, 11, 96-101. https://doi.org/10.1142/S0192415X83000161

[48] Yuan, H.-D., Kim, S.-J., Quan, H.-Y., Huang, B. and Chung, S.-H. (2010) Ginseng Leaf Extract Prevents High Fat Diet-Induced Hyperglycemia and Hyperlipidemia through AMPK Activation. Journal of Ginseng Research, 34, 369-375. https://doi.org/10.5142/igr.2010.34.4.369

[49] Kim, S.-H. and Park, K.-S. (2003) Effects of Panax ginseng Extract on Lipid Metabolism in Humans. Pharmacological Research, 48, 511-513.

https://doi.org/10.1016/S1043-6618(03)00189-0

[50] Borrelli, F., Colalto, C., Delfino, D.V., Iriti, M. and Izzo, A.A. (2018) Herbal Dietary Supplements for Erectile Dysfunction: A Systematic Review and Meta-Analysis. Drugs, 78, 643-673. https://doi.org/10.1007/s40265-018-0897-3

[51] Choi, H.-K., Choi, Y.-D. and Lee, W.-H. (1998) Clincal Efficacy of Korean Red Ginseng for Erectile Dysfunction-Multi-National Approach. Proceedings of the Ginseng Society Conference, 208-215.

[52] Choi, Y., Park, C., Jang, J., Kim, S., Jeon, H., Kim, W., et al. (2013) Effects of Korean Ginseng Berry Extract on Sexual Function in Men with Erectile Dysfunction: A 
Multicenter, Placebo-Controlled, Double-Blind Clinical Study. International Journal of Impotence Research, 25, 45-50. https://doi.org/10.1038/ijir.2012.45

[53] De Andrade, E., De Mesquita, A.A., de Almeida Claro, J., De Andrade, P.M., Ortiz, V., Paranhos, M., et al. (2007) Study of the Efficacy of Korean Red Ginseng in the Treatment of Erectile Dysfunction. Asian Journal of Andrology, 9, 241-244. https://doi.org/10.1111/j.1745-7262.2007.00210.x

[54] Jang, D.J., Lee, M.S., Shin, B.C., Lee, Y.C. and Ernst, E. (2008) Red Ginseng for Treating Erectile Dysfunction: A Systematic Review. British Journal of Clinical Pharmacology, 66, 444-450. https://doi.org/10.1111/j.1365-2125.2008.03236.x

[55] Kim, T.-H., Jeon, S.H., Hahn, E.-J., Paek, K.-Y., Park, J.K., Youn, N.Y., et al. (2009) Effects of Tissue-Cultured Mountain Ginseng (Panax ginseng CA Meyer) Extract on Male Patients with Erectile Dysfunction. Asian Journal of Andrology, 11, 356-361. https://doi.org/10.1038/aja.2008.32

[56] Leisegang, K. and Finelli, R. (2021) Alternative Medicine and Herbal Remedies in the Treatment of Erectile Dysfunction: A Systematic Review. Arab Journal of Urology, 19, 323-339. https://doi.org/10.1080/2090598X.2021.1926753

[57] Ernst, E., Posadzki, P. and Lee, M.S. (2011) Complementary and Alternative Medicine (CAM) for Sexual Dysfunction and Erectile Dysfunction in Older Men and Women: An Overview of Systematic Reviews. Maturitas, 70, 37-41. https://doi.org/10.1016/j.maturitas.2011.06.011

[58] Yamashita, S.-I. (2018) Effects of Sanchi Ginseng Extract on the Sexual Function in Japanese Men-A Randomized, Double-Blind, Placebo-Controlled, Parallel-Group Trial. Japanese Pharmacology and Therapeutics, 46, 561-580.

[59] Chen, X. (1996) Cardiovascular Protection by Ginsenosides and Their Nitric Oxide Releasing Action. Clinical and Experimental Pharmacology and Physiology, 23, 728732. https://doi.org/10.1111/j.1440-1681.1996.tb01767.x

[60] Han, K.H., Choe, S.C., Kim, H.S., Sohn, D.W., Nam, K.Y., Oh, B.H., et al. (1998) Effect of Red Ginseng on Blood Pressure in Patients with Essential Hypertension and White Coat Hypertension. The American Journal of Chinese Medicine, 26, 199 209. https://doi.org/10.1142/S0192415X98000257

[61] Wood, W.B., Roh, B.L. and White, R.P. (1964) Cardiovascular Actions of Panax ginseng in Dogs. The Japanese Journal of Pharmacology, 14, 284-294. https://doi.org/10.1254/ijp.14.284

[62] Hur, M.-H., Lee, M.-S., Yang, H.-J., Kim, C., Bae, I.-L. and Ernst, E. (2010) Ginseng for Reducing the Blood Pressure in Patients with Hypertension: A Systematic Review and Meta-Analysis. Journal of Ginseng Research, 34, 342-347. https://doi.org/10.5142/jgr.2010.34.4.342

[63] World Health Organization (2007) Prevention of Cardiovascular Disease: Guidelines for Assessment and Management of Cardiovascular Risk. WHO. https://www.who.int/cardiovascular diseases/guidelines/Full\%20text.pdf

[64] Sotaniemi, E.A., Haapakoski, E. and Rautio, A. (1995) Ginseng Therapy in NonInsulin-Dependent Diabetic Patients: Effects on Psychophysical Performance, Glucose Homeostasis, Serum Lipids, Serum Aminoterminalpropeptide Concentration, and Body Weight. Diabetes Care, 18, 1373-1375. https://doi.org/10.2337/diacare.18.10.1373

[65] Vuksan, V., Xu, Z.Z., Jovanovski, E., Jenkins, A.L., Beljan-Zdravkovic, U., Sievenpiper, J.L., Stavro, P.M., Zurbau, A., Duvnjak, L. and Li, M.Z. (2019) Efficacy and Safety of American Ginseng (Panax quinquefolius L.) Extract on Glycemic Control and Cardiovascular Risk Factors in Individuals with Type 2 Diabetes: A Double- 
Blind, Randomized, Cross-Over Clinical Trial. European Journal of Nutrition, 58, 1237-1245. https://link.springer.com/article/10.1007/s00394-018-1642-0

[66] Ryu, J.-K., Lee, T., Kim, D.-J., Park, I.-S., Yoon, S.-M., Lee, H.-S., et al. (2005) Free Radical-Scavenging Activity of Korean Red Ginseng for Erectile Dysfunction in NonInsulin-Dependent Diabetes Mellitus Rats. Urology, 65, 611-615.

https://doi.org/10.1016/j.urology.2004.10.038

[67] Bakircioglu, M.E., Hsu, K., El-Sakka, A., Sievert, K.-D., Lin, C.S. and Lue, T.F. (2000) Effect of a Chinese Herbal Medicine Mixture on a Rat Model of Hypercholesterolemic Erectile Dysfunction. The Journal of Urology, 164, 1798-1801. https://doi.org/10.1016/S0022-5347(05)67109-1

[68] Delui, M.H., Fatehi, H., Manavifar, M., Amini, M., Ghayour-Mobarhan, M., Zahedi, M., et al. (2013) The Effects of Panax ginseng on Lipid Profile, Pro-Oxidant: Antioxidant Status and High-Sensitivity C Reactive Protein Levels in Hyperlipidemic Patients in Iran. International Journal of Preventive Medicine, 4, 10451051.

[69] Moyad, M.A. and Park, K. (2012) What Do Most Erectile Dysfunction Guidelines Have in Common? No Evidence-Based Discussion or Recommendation of HeartHealthy Lifestyle Changes and/or Panax ginseng. Asian Journal of Andrology, 14, 830-841. https://doi.org/10.1038/aja.2012.82 


\section{List of Abbreviation (Sorted Alphabetically)}

95\% CI

AGEs

AMP: ATP

AMPK

Cyclic AMP

Cyclic GMP

DIED

ED

eNOS

GAQ

GS

HbAlc

HDL

IIEF

IIEF-5

IIEF-15

KRG

LDL

n

NO

$\mathrm{P}$

PDE5

PEDT

RCTs

Rg1

RR

S2

S4

SKGB

TC/HDL

TMGE

US
95\% Confidence Interval

Advanced Glycation End-products

Adenosine Monophosphate:Adenosine Triphosphate

Adenosine Monophosphate-activated Protein Kinase

Cyclic Adenosine Monophosphate

Cyclic Guanosine Monophosphate

Diabetes-induced Erectile Dysfunction

Erectile Dysfunction

Endothelial Nitric Oxide Synthase

Global Assessment Questionnaire

Ginsenosides

Hemoglobin A1c

High-Density Lipoprotein

International Index of Erectile Function

International Index of Erectile Function -5

International Index of Erectile Function -15

Korean Red Ginseng

Low-Density Lipoproteins

Number

Nitrous Oxide

Probability

Phosphodiesterase Type 5

Premature Ejaculation Diagnostic Tool

Randomized Controlled Trials

Ginsenoside Rg1

Risk Ratio

Sacral Spine Nerve 2

Sacral Spine Nerve 4

Standardized Korean Ginseng Berry

Total Cholesterol/High-Density Lipoprotein

Tissue-cultured Mountain Ginseng Extract

United States 